\title{
An Economic Analysis of Production of Onion (Allium Cepa) in Mahabubnagar District of Telangana
}

\author{
Munasu vikas $1 *$, Dr. Ramchandra2 \\ Department of Agriculture Economics, \\ Sam Higginbottom University of Agriculture Technology and sciences \\ Prayagraj-211007, Uttar Pradesh, India
}

\begin{abstract}
The present study entitled "An Economic Analysis of Production of onion in Mahabubnagar district of Telangana" was conducted in year 2019-2020. The study made use of a multi stage sampling and random sampling technique to select 90 farmers among the selected villages. Data for the selected study were collected with the aid of well-structured questionnaires . Data collected were analyzed using tabulation method along wit required statistical tool. The Production of onion has increased in the area largely due to productivity increase and increase in the area under crop. Resource use structure in onion was found to be varied among the size groups. The per cost of cultivation was varied among the size groups of onion was highest on small size(Rs.63718.2/hac) and lowest on large size(Rs.61250.0/hac) and medium (Rs.62842.0/hac). The input output ratio is highest on large size farms and lowest on small size farms
\end{abstract}

Keywords:- Onion, Cost and return, input output ratio.

\section{INTRODUCTION}

Onion belongs to the family Alliaceae, origin asia. It is one of the most important commercial vegetable crop grown by large, small, and medium farmers in different parts of the country, Onion is the important vegetable crop widely used in all households all the year round. Onions are good source of dietary fiber, folic acid and contain calcium, iron, high protein quality and medicinal values. India is the second largest producer of onion in the world. Indian onions are famous for their pungency. Onion is mostly consumed vegetable crop in india. Maharashtra alone produces 70 percent of onions in the country.

\section{RESEARCH METHODOLOGY}

The studywas conducted in Mahabubnagar district of Telangana which is one of the 31 districts of Telangana. Mahabubnagar district comprises of 64 blocks among 2 blocks were selected i.e Gadwal and waddepalle blocks were selected for the study. A listof 6villages were selected randomly out of them. A list of all Onion farmers/ respondents is prepared with the help of head of the villages pradhan or head of the each selected villages in both block, there after farmers/respondents is categorized in 3 size groups on the basis of their land holding and then from each village $10 \%$ farmers were selected randomly from all the different size of farm groups. Data for the study was collected from all 90 farmers randomly i.e 43 small farmers, 29 medium farmers and 18 large farmers. Tabulation method is used for analysis of data along with required statistical tools for the interpretation of the results for the objectives.

\begin{tabular}{|c|c|c|c|c|c|}
\hline S.NO & Particulars & Small & Medium & large & Sample average \\
\hline 1 & Hired Human Labour & $\begin{array}{c}6750 \\
(10.60)\end{array}$ & $\begin{array}{c}7000 \\
(11.13)\end{array}$ & $\begin{array}{c}7250 \\
(11.83)\end{array}$ & $\begin{array}{c}7000 \\
(11.18)\end{array}$ \\
\hline 2 & Machinery charges & $\begin{array}{c}3750 \\
(5.88)\end{array}$ & $\begin{array}{c}3900 \\
(6.60)\end{array}$ & $\begin{array}{c}3300 \\
(5.38)\end{array}$ & $\begin{array}{c}3650 \\
(5.83)\end{array}$ \\
\hline 3 & Cost of seed & $\begin{array}{l}4700 \\
(7.37) \\
\end{array}$ & $\begin{array}{c}4400 \\
(7.00) \\
\end{array}$ & $\begin{array}{c}4200 \\
(6.85) \\
\end{array}$ & $\begin{array}{c}4433.3 \\
(7.08) \\
\end{array}$ \\
\hline 4 & Cost of FYM & $\begin{array}{l}5500 \\
(8.63)\end{array}$ & $\begin{array}{r}5350 \\
(8.51)\end{array}$ & $\begin{array}{c}5200 \\
(8.48) \\
\end{array}$ & $\begin{array}{c}5350 \\
(8.54)\end{array}$ \\
\hline 5 & Cost of Fertilizers & $\begin{array}{c}8000 \\
(12.55)\end{array}$ & $\begin{array}{c}7850 \\
(12.49)\end{array}$ & $\begin{array}{c}7700 \\
(12.57)\end{array}$ & $\begin{array}{c}7850 \\
(12.53) \\
\end{array}$ \\
\hline 6 & Cost of irrigation & $\begin{array}{c}9000 \\
(14.12)\end{array}$ & $\begin{array}{c}9050 \\
(14.40)\end{array}$ & $\begin{array}{c}9150 \\
(14.93)\end{array}$ & $\begin{array}{l}9066.6 \\
(14.48)\end{array}$ \\
\hline 7 & Cost of Plant chemicals & $\begin{array}{c}3800 \\
(5.96)\end{array}$ & $\begin{array}{c}3550 \\
(5.64)\end{array}$ & $\begin{array}{c}3150 \\
(5.14)\end{array}$ & $\begin{array}{c}3500 \\
(5.59)\end{array}$ \\
\hline 8 & Interest on working capital@8\% & $\begin{array}{c}3320 \\
(5.21)\end{array}$ & $\begin{array}{c}3288 \\
(5.23)\end{array}$ & $\begin{array}{c}3196 \\
(5.21)\end{array}$ & $\begin{array}{c}3268 \\
(5.22)\end{array}$ \\
\hline 9 & Depreciation on fixed capital & $\begin{array}{l}1620 \\
(2.54)\end{array}$ & $\begin{array}{c}1490 \\
(2.37)\end{array}$ & $\begin{array}{c}1400 \\
(2.28)\end{array}$ & $\begin{array}{l}1503.2 \\
(2.04)\end{array}$ \\
\hline
\end{tabular}


ISSN No:-2456-2165

\begin{tabular}{|c|c|c|c|c|c|}
\hline 10 & Land Revenue Paid to Govt & 0 & 0 & 0 & 0 \\
\hline 11 & Rental Value of own land & $\begin{array}{c}10000 \\
(15.69)\end{array}$ & $\begin{array}{c}10000 \\
(15.91)\end{array}$ & $\begin{array}{c}10000 \\
(16.32)\end{array}$ & $\begin{array}{c}10000 \\
(15.97)\end{array}$ \\
\hline 12 & Interest on Fixed Capital @ 11\% & $\begin{array}{l}1278.2 \\
(2.00)\end{array}$ & $\begin{array}{l}1263.9 \\
(2.01)\end{array}$ & $\begin{array}{l}1254 \\
(2.04)\end{array}$ & $\begin{array}{l}1265.3 \\
(2.02)\end{array}$ \\
\hline 13 & Family Labour charges & $\begin{array}{c}6000 \\
(9.41)\end{array}$ & $\begin{array}{l}5700 \\
(9.07)\end{array}$ & $\begin{array}{c}5450 \\
(8.89)\end{array}$ & $\begin{array}{c}5716.6 \\
(9.13) \\
\end{array}$ \\
\hline 14 & Total cost of cultivation & $\begin{array}{c}63,718.2 \\
(100)\end{array}$ & $\begin{array}{c}62842 \\
(100) \\
\end{array}$ & $\begin{array}{l}61250 \\
(100)\end{array}$ & $\begin{array}{c}62603.3 \\
(100) \\
\end{array}$ \\
\hline
\end{tabular}

Table 1:- Resource use and Cost and Cultivation of Onion crop per hectare in different Size of Farms Group

The table 1 reveals that among different size of farms, total cost incurred by the small farms were high (Rs.63,718.2/ha) as compared to medium and large size farms (Rs.62842/ha and Rs.61250/ha). Sample average for total cost was Rs.62603.3/ha in different size of farms group. The cost of human labour, fertilizers, seeds were the items for the cost with major share in the variable costs, because most of the operations like harvesting and weeding were human labour intensive operations and the other operations like land preparation and inter culture were bullock labour cost of human labour intensive. The distribution of pattern of operational cost under various inputs revealed that cost of human labour was highest in small size farms (Rs.6750/ha), as compared to medium size farms (Rs.7000/ha) and lowest in large size farms (Rs.7250/ha). Machinery cost was Rs.3750/ha in small size farms and for medium size farms was (Rs.3900/ha) and large size farms (Rs.3300/ha). The cost of seeds was highest in small size farms (Rs.4700/ha), as compared to medium size farms (Rs.4400/ha) and lowest in large size farms (Rs.4200/ha). As Onion would respond well with chemical fertilizer so the cost of farm yard manure used was ranged from Rs.5500/ha in large size farms, Rs.5350/ha in medium size farms and 5200 in small size farms. Whereas, the expenditure on fertilizers was highest in small size farms (Rs.8000/ha), as compared to medium size farm (Rs.7850/ha) and lowest in large size farms (7700/ha) respectively. Sample average for depreciation on fixed resources was Rs.1503.3. Interest on working capital Rs.3268, interest on fixed capital was Rs.1265.3, labour charges for different size of farms group is Rs.5716.6.The cost rental value of own land was Rs.10000/ha in large, medium and large size of farms group respectively. Sample average for rental value of own land was Rs.10000/ha for different size of farm groups.

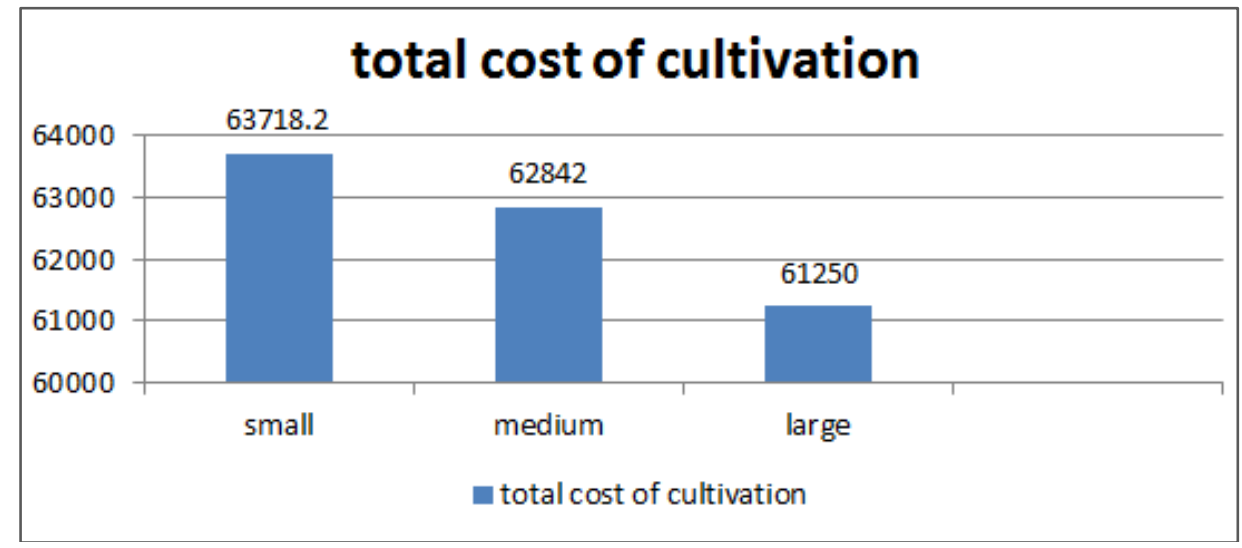

Fig 1

\begin{tabular}{|c|c|c|c|c|c|c|c|c|}
\hline Source & Df & SS & MSS & F Cal & $\begin{array}{c}\text { F Tab } \\
5 \%\end{array}$ & Result & S .Ed & C.D at 5\% \\
\hline Channel & 2 & 240873.3 & 120436.6 & 4.08 & 3.40 & S & 140.15 & 288.70 \\
\hline Particular & 12 & 337266459.5 & 28105538.29 & 953.83 & 2.18 & S & 67.32 & 186.47 \\
\hline Error & 24 & 707177.4 & 29465.73 & & & & & \\
\hline Total & 38 & & & & & & \\
\hline
\end{tabular}

Table 2

In the above ANOVA table, in due to size group degrees of freedom is 2, sum of squares is 240873.3 , mean sum of squares is 120436.6 , F. Calculated value is 4.087347, F. tabulated value @ 5\% is 3.40, result is significant, standard deviation is 140.15 and critical difference @ 5\% is 288.709. In due to particulars degrees of freedom is 12 , sum of squares is 337266459.5, mean sum of squares is $28105538.29, \mathrm{~F}$. Calculated value is $953.8383, \mathrm{~F}$. tabulated value is 2.18 , result is significant, standard deviation is 67.32 and critical difference @ 5\% is 186.4764 In error degrees of freedom is 24, sum of squares is 707177.4 and mean sum of squares is 29465.73 .74 . 
ISSN No:-2456-2165

\begin{tabular}{|c|c|c|c|c|c|}
\hline S. No & Cost concepts & small & Medium & Large & Sample average \\
\hline $\mathbf{1}$ & Cost A1 & 46440 & 45878 & 44546 & 45621.3 \\
\hline $\mathbf{2}$ & Cost A2 & 56440 & 55878 & 54546 & 55621.3 \\
\hline $\mathbf{3}$ & Cost B & 57718.2 & 57141.9 & 55800 & 56886.7 \\
\hline $\mathbf{4}$ & Cost C & 63718.2 & 62842 & 61250 & 62603.3 \\
\hline
\end{tabular}

Table 3:- cost concepts of onion per hectare in different size farm groups

Table 3 reveals that cost concepts on different size of farms group per hectare. Cost $\mathrm{A}_{1}$ was highest in small size farms (Rs.46440/ha) followed by medium size farms (Rs.45878/ha) and large size farms (Rs.44546/ha) respectively. Cost $\mathrm{A}_{2}$ in small, medium and large size of farms group was Rs.56440/ha, Rs.55878/ha and Rs.54546/ha respectively. Cost B was highest in small size farms (Rs.57718.2/ha) and lowest in large size farms (Rs.55800/ha) as compared to medium size farms (Rs.57141,9/ha) respectively. Cost C was highest in small size farms (Rs.63718.2/ha) and lowest in large size farms (Rs.61250/ha) as compared to medium size farms (Rs.62842/ha) respectively. Sample average for Cost $\mathrm{A}_{2}$, Cost B and Cost C was Rs.55621.3.7/ha, Rs.56886.7/ha and Rs.62603.3/ha in different size of farms group.

\begin{tabular}{|c|c|c|c|c|c|}
\hline S.No & Particulars & Small & Medium & Large & Sample average \\
\hline 1 & Total cost of cultivation & 63718.2 & 62842 & 61250 & 62603.4 \\
\hline 2 & Yield in quintals per hactare & 125 & 126.3 & 127 & 126.1 \\
\hline 3 & Cost of production (Rs/qtls) & 509.74 & 497.54 & 482.28 & 496.52 \\
\hline 4 & Returns(Rs/hac) & 900 & 900 & 900 & 900 \\
\hline 5 & Gross return per hectare & 112500 & 113700 & 114300 & 113500 \\
\hline 6 & Net returns per hectare & 48781.8 & 50858 & 53050 & 50896.6 \\
\hline 7 & Family labour income & 6000 & 5700 & 5450 & 5716.6 \\
\hline 8 & Family business income & 56060 & 57822 & 59754 & 57887.6 \\
\hline 9 & Input output ratio & $1: 1.76$ & $1: 1.80$ & $1: 1.86$ & $1: 1.80$ \\
\hline
\end{tabular}

Table 4:- Cost and returns in Onion Per hectare in different size of farms.

Table 4 Reveals that cost and returns in Onion cultivation in different size of farms group. Among different size of farms groups, the total cost of cultivation incurred by the small farms were high (Rs.63718.2/ha) as compared to medium (Rs.62842/ha) and large farms (Rs.61250/ha). Sample average for total cost of cultivation was Rs.62603.4/ha in different size of farms group. Yield is less in small size farms is $125 \mathrm{qtls} / \mathrm{ha}$, as compared to medium 126.3qtls/ha and large size farms group is $127 \mathrm{qtls} / \mathrm{ha}$. Sample average for Yield is $126.1 \mathrm{qtl} / \mathrm{ha}$. The gross returns obtained per hectare by large size farms were high (Rs.114300/ha) compared to medium and small size farms (Rs.113700/ha and Rs.112500/ha) respectively. The net returns per hectare obtained by large size farms were (Rs.53050/ha) as compared to medium and small size farms (Rs.50858/ha and Rs.48781.8/ha) respectively. The average yield of Onion in different size of farms group was 126.1qtls/ha. The yield was highest in case of large size farms (127qtls/ha) as compared to medium (126.3qtls/ha) and small size farms (125qtls/has) respectively. Average cost of production per quintal was Rs.496.52qtl/ha. Gross returns per hectare was Rs.113500. Input output Ratio was highest in large size farms (1:1.86) followed by medium size farms (1:1.80) and lowest in small size farms group $(1: 1.76)$.

\begin{tabular}{|c|c|c|c|c|c|c|c|c|}
\hline Source & d f & S.S & M.S.S & F. Cal & F. Tab 5\% & Result & S .Ed & C.D at 5\% \\
\hline Size group & 2 & 108.779 & 54.38973 & 0.800241 & 6.9427 & NS & 6.73 & 18.6421 \\
\hline Particular & 2 & 898928.3 & 449464.1 & 6613.002 & 6.9427 & S & 6.73 & 18.6421 \\
\hline Error & 4 & 271.8669 & 67.96673 & & & & & \\
\hline Total & 8 & & & & & & & \\
\hline
\end{tabular}

Table 5

In the above Anova table, in due to size group degrees of freedom is 2, sum of squares is 108.77, mean sum of squares is $54.38973, \mathrm{~F}$. Calculated value is $0.800241, \mathrm{~F}$. tabulated value @ 5\% is 6.94, result is not significant, standard deviation is 6.73 and critical difference is @ $5 \%$ is 18.6421. In due to particulars, degrees of freedom is 2 , sum of squares is 898928.3, mean sum of squares is 449464.1, F. Calculated value is 6613.002, F. tabulated value @ 5\% is 6.94, result is significant, standard deviation is 6.73 and critical difference is 18.6421 . In error, degree of freedom is 4 , sum of squares is 271.8669 .30 and mean sum of squares is 67.96673 .

\section{CONCLUSION}

The production of onion has increased largely due to productivity increase and increase in the area under the crop. The acreages under onion not influenced by improvement in the productivity but it largely depended on the other factors like rain fall and price of this crop .The cropping pattern was dominated by onion crop followed by groundnut, sugarcane and paddy. Resource use structure in onion was found to be varied among the size groups of holdings. Production cost of onion was varied according to size group of holdings. The per hectare cost of cultivation 
of onion was the highest on the small size farms and lowest on large size farms. Among the rental value of land, hired labour, fertilizers, manures, seeds were the major items of cost. The cost of cultivation varied among the size groups of onion growers.

\section{REFERENCES}

[1]. Abdelaziz, A.A. (2008). Economics of Onion Production in the Northern Part of Omdurman Province, Khartoum State. Albuhutb, 12 (1) : 42-51

[2]. AminuandC.Abbao (2006). Seasonality and gross real returns to storage of onion markets in Jigawa state. Journal of Agriculture Economics and extension, 44(2):181-188.

[3]. Ali A, M.A. Niazi and N. Akmal. (2005). Comparative analysis of cost and return of Potato, Onion and Tomato in Balouchistan. Sarhad J. Agric. 21(4):785-791.

[4]. Balappa,S.R. and Hugas,L.B. (2003). An economic evaluation of onion production and its marketing system in Karnataka. Agricultural Marketing. 46(2):22-26.

[5]. Chandrashekhar, (2007). Analysis of onion Production and marketing behaviour of farmers in Gadag district, Karnataka. M.Sc.(Agri.) Thesis, Univ. Agric Sci., Dharwad, Karnataka, India. 